\title{
DISKURSUS ISLAMIC SOCIAL REPORTING SEBAGAI AKUNTABILITAS BERBASIS SYARIAH
}

\author{
Bayu Tri Cahya \\ Institut Agama Islam Negeri (IAIN) Kudus \\ Jl. Conge Ngembalrejo 51, Ngebalrejo, Bae, Kab. Kudus, Jawa Tengah 59322 \\ E-mail: cahyab380@gmail.com
}

\begin{abstract}
Islamic Discourse on Islamic Social Reporting as Sharia Based Accountibility. This article seeks to reveal representations of sharia-based accountability in the concept of Islamic Social Reporting (ISR) as an effort to provide relevant information in accordance with the spiritual needs of Muslim decision-makers. This study is conducted by literature study based on Islamic framework and previous research results. From these reviews, it provides evidence that accountability is crucial to making responsive attitudes to entities, in which they gain authority and recognize that there must be an accountability attitude to be undertaken. Sharia-based accountability is needed for the Muslim community to demonstrate accountability to fellow human beings, society and God. Implementation of ISR as a form of accountability is based on the principles and philosophies extracted from the Quran and Sunnah as a guide in various life activities. Therefore, the implementation of ISR is based on spiritual and transcendental elements which are believed to be able to solve and mitigate social problems, both within a business entity and in society, especially for the empowerment of people's economy and humanism.
\end{abstract}

Keywords: accountability; Islamic Social Reporting; spiritual perspective.

\begin{abstract}
Abstrak: Diskursus Islamic Social Reporting sebagai Akuntabilitas Berbasis Syariah. Artikel ini bertujuan untuk mengungkapkan penyajian akuntabilitas berbasis syariah kepada stakeholder perusahaan dalam konsep Islamic Social Reporting (ISR) sebagai upaya untuk menyediakan informasi yang relevan sesuai dengan kebutuhan spiritual para pengguna laporan keuangan. Kajian ini dilakukan dengan studi kepustakaan yang didasarkan atas kerangka Islami dan hasil penelitian terdahulu. Tulisan tersebut memberikan bukti bahwa akuntabilitas sangat penting untuk membuat sikap responsif terhadap entitas yang diperoleh serta menyadari bahwa harus ada sikap pertanggungjawaban yang harus dilakukan. Akuntabilitas berbasis syariah dibutuhkan bagi komunitas muslim dengan tujuan untuk menunjukkan pertanggungjawaban kepada sesama manusia, masyarakat, dan Allah Swt. Implementasi ISR sebagai bentuk pertanggungjawaban didasarkan pada prinsip dan falsafah yang digali dari Alquran dan sunah sebagai pedoman dalam berbagai aktivitas kehidupan. Oleh karena itu, pelaksanaan ISR sangat mendasarkan pada unsur spiritual dan transendental yang diyakini dapat menyelesaikan serta meringankan masalah sosial, baik yang terjadi dalam suatu entitas bisnis maupun dalam masyarakat terutama untuk pemberdayaan ekonomi masyarakat.
\end{abstract}

Kata kunci: akuntabilitas; pelaporan sosial Islam; perspektif spiritual.

\section{Pendahuluan}

Anggapan terhadap akuntansi Islam saat ini tentu masih banyak yang dipertanyakan orang. Hal ini sebenarnya merupakan hal yang wajar bila dikaitkan dengan batasan atau definisi yang dipakai sertapengetahuan ilmiah dari masing-masing pencetusnya. Namun lambat laun semua yang dahulunya masih dalam taraf konsep akhirnya muncul juga sebagai fenomena empiris seperti munculnya sebuah konsep akuntabilitas berbasis syariah, yaitu Islamic Social
Reporting (ISR). ISR merupakan salah satu cara pengungkapan terhadap kondisi sebuah entitas perusahaan secara penuh dalam konteks Islam. ${ }^{1}$ ISR ini pertama kali dikemukakan oleh Haniffa ${ }^{2}$, kemudian dikembangkan secara ekstensif oleh

'Rohana Othman, A. Md. Thani, dan dan E.K. Ghani, "Determinants of Islamic Social Reporting Among Top Shariah-Approved Companies in Bursa Malaysia", Research Journal of International Studies, Vol. 12, 2009, h. 5.

2 R. Haniffa, "Social Reporting Disclosure-An Islamic Perspective", Indonesian Management \& Accounting Research, Vol. 2, 2002, h.129. 
Othman, Thani, dan Ghani secara spesifik di Malaysia. 3

Munculnya konsep ISR diharapkan melahirkan praktik akuntansi yang sesuai dengan syariat Islam sehingga memberikan konstribusi yang berarti kepada kemajuan ekonomi dan praktik bisnis serta perdagangan yang lebih jujur dan adil. Oleh karena itu, dengan mempersiapkan konsep akuntabilitas sosial terkait dengan prinsip pengungkapan maka akan terpenuhinya kebutuhan publik terhadap suatu informasi atau pengungkapan yang berdasarkan prinsipprinsip syariah. Dalam konteks Islam, masyarakat mempunyai hak untuk mengetahui berbagai informasi mengenai aktivitas organisasi. Hal ini dilakukan untuk melihat apakah perusahaan tetap melakukan kegiatannya sesuai syariah dan mencapai tujuan yang telah ditetapkan. Indeks ISR merupakan tolok ukur pelaksanakaan aktivitas sosial perbankan syariah yang berisi kompilasi item-item standar Corporate Social Responsibility (CSR) Conduct and Disclousure for Islamic Financial Institusions yang ditetapkan oleh AAOIFI (Accounting and Auditing Organization for Islamic Financial Institutions) pada Governance Standard for Islamic Social Institusions No.7 yang kemudian dikembangkan lebih lanjut oleh para peneliti mengenai item-item CSR yang seharusnya diungkapkan oleh suatu entitas Islam.

Indeks ISR merupakan cara yang dibangun untuk mengetahui sejauh mana penerapan aktivitas sosial yang berbasis Islami dalam laporan tahunan perusahaan. Pada umumnya cakupan Indeks ISR yang mengacu pada literatur dan penelitian-penelitian terdahulu meliputi enam tema pengungkapan, yaitu: finance and investment theme, product and service theme, employees theme, society theme, environment theme, corporate governance theme. Tema-tema pengungkapan ini meliputi pelaporan ekonomi yang harus mendasarkan pada prinsip akadakad syariah, yaitu tidak mengandung zhulûm (kezaliman), ribâ, maysîr (judi), gharâr (penipuan), barang yang haram dan membahayakan.

Demikian menariknya konsep ISR, penulis

3 Rohana Othman, A. Md. Thani, dan E.K. Ghani, "Determinants of Islamic Social Reporting..., h. 2. berusaha menggali lebih dalam tentang bagaimana hubungan akuntansi dan akuntabilitas yang terefleksikan dalam konsep ISR. Akuntansi menjadi satu kajian yang berkenaan dengan kelakuan manusia dalam menggunakan sumber-sumber untuk memenuhi keperluan mereka. Dalam pengertian Islam, akuntansi merupakan salah satu ilmu pengetahuan sosial yang mengkaji masalah masalah ekonomi manusia yang didasarkan syariat Islam yaitu kepada Alquran dan hadis. Selain itu, permasalahan pengelolaan, penggunaan harta, pertukaran barang, uang, dan jasa menjadi bagian tak terpisahkan dalam kehidupan ini. Maka dari itu, sudah menjadi kewajiban setiap muslim yang melakukan pelaku kegiatan harus mengenal hukum-hukum syariat Islam yang berkaitan dengan transaksi ekonomi, termasuk dalam mengimplementasikan ISR. Oleh sebab itu, ISR digunakan sebagai dasar dan arah pengembangan tanggung jawab sosial khususnya untuk entitas bisnis yang berbasis syariah. ${ }^{4} \mathrm{Hal}$ inilah yang dijadikan pondasi yang ditujukan untuk mengatur kehidupan manusia dalam urusan duniawi dan sosial kemasyarakatan. ${ }^{5}$

Kajian terhadap ISR ini juga merupakan jawaban atas keterbatasan laporan sosial konvensional. Hal ini dikarenakan konsep ISR tidak hanya mendasarkan pada aspek moral dan etika saja, tetapi juga terjiwai oleh unsur spiritual (ketentuan syariah Islam). Kajian ini juga membantu para pengambil keputusan muslim untuk mengetahui seberapa jauh perusahaan yang berbasis syariah dalam menjalankan aktivitas dan pelaporan yang sesuai ketentuan Islam. Hal ini tentu saja dilakukan dalam rangka pemenuhan kewajiban terhadap Allah Swt, dan masyarakat sekitarnya. ${ }^{6}$ Secara lebih mendalam, kajian ini dilakukan dengan studi kepustakaan yang didasarkan atas kerangka Islami dan hasil penelitian-penelitian terdahulu. Dalam hal ini, mayoritas penelitian-peneltian terdahulu yang membahas mengenai ISR hampir kesemuanya

${ }^{4}$ Bayu Tri Cahya dan Umi Hanifah, "Meretas Aktualitas Islamic Social Report: Sebagai Corporate Social Responsibilities Framing Berbasis Syariah, (Dalam Pendekatan Filosofis)", Jurnal BISNIS, Vol. 4, No. 1, Juni 2016, h. 6.

${ }^{5}$ Hendi Suhendi, Fiqh Muamalah, (Bandung: Gunung Djati Press, 1997), h. 5.

${ }^{6}$ R. Haniffa,"Social Reporting Disclosure..., h. 132. 
menggunakan metode penelitian kuantitatif dengan jenis explanatory research.

\section{Akuntansi dalam Sejarah Islam}

Alquran memberikan gambaran bagaimana seorang muslim dalam melakukan perniagaan (muamalah). Pada prinsipnya, ketika melakukan perniagaan terdapat kaidah-kaidah yang harus dijaga oleh para peniaga. Kaidah kaidah tersebut selanjutnya dijadikan sebagai tolak ukur etika dalam bekerja. Bagi masyarakat Islam, prinsip dasar ketika melakuan pekerjaan tentunya harus sesuai dengan etika kerja Islam itu sendiri. Oleh karena itu jauh hari sebelumnya masalah etika kerja dalam melakukan muamalat, telah disinggung dalam Alquran dalam Q.S Al-Baqarah [ 2]: 282-283.

Penggunaan akuntansi dan perkembangannya di negara Islam ditandai dengan adanya manuskrip yang ditulis pada tahun $765 \mathrm{H} / 1363$ M. Manuskrip ini adalah karya seorang penulis muslim, yaitu 'Abdullah bin Muhammad bin Kayah al-Mazindarani, dan diberi judul "Risalah Falaqiyah Kitab As Siyaqat". 7 Tulisan disimpan di perpustakaan Sultan Sulaiman Al-Hanuni di Istambul, Turki. Tercatat di bagian manuskrip dengan No. 2756, dan memuat tentang akuntansi dan sistem akuntansi di negara Islam. Huruf yang digunakan dalam tulisan ini adalah huruf Arab, tetapi bahasa yang digunakan terkadang bahasa Arab, terkadang bahasa Parsi dan terkadang pula bahasa turki yang populer di daulat Utsmaniyah.

Buku tersebut ditulis kurang lebih 131 tahun sebelum munculnya karya Pacioli yang bukunya pertama kali dicetak tentang sistem pencatatan berpasangan double entry, sedangkan AlMazindarani masih dalam bentuk manuskrip, belum dicetak dan belum diterbitkan. ${ }^{8}$ Dalam bukunya yang masih dalam bentuk manuskrip itu Al-Mazindarani menjelaskan hal-hal berikut ini:

1. Sistem akuntansi yang populer pada saat itu dan pelaksanaan pembukuan yang khusus bagi setiap sistem akuntansi

7 Sukma Lesmana dan Atma Hayat, Teori Akuntansi, (Jakarta: Citapustaka Media, 2015), h. 6.

${ }^{8}$ Arfan Ikhsan, Sukma Lesmana dan Atma Hayat, Teori Akuntansi..., h.6.
2. Macam-macam buku akuntansi yang wajib digunakan untuk mencatat transaksi keuangan

3. Cara menangani kekurangan dan kelebihan, yakni penyetaraan.

Al-Mazindarani juga menjelaskan pelaksanaan pembukaan yang populer pada saaat itu dan kewajiban kewajiban yang harus diikuti. Sebagai contoh pelaksanaan yang disebutkan oleh Al-Mazindarani adalah sebagai berikut "Ketika mencatat di buku buku akuntansi, harus dimulai dengan kata-kata Basmallah, "Bismillahirahmanirahim". Hal ini juga yang ditegaskan oleh Lucas Pacioli, dimana harus dimulai dengan ungkapan "Bismillah".

Disamping apa yang telah disebutkan, perkembangan akuntansi mencakup penyiapan laporan keuangan, karena negara Islam telah mengenal tingkat tinggi. Laporan keuangan ini pernah dibuat berdasarkan fakta buku-buku akuntansi yang digunakan. Diantara laporan yang terkenal di negara Islam adalah al-Khithâmah dan al-Khitâmatul Jamî̀ah. Al-Khithâmah adalah laporan keuangan bulanan yang dibuat pada setiap akhir bulan. Pelaporan ini memuat pemasukan dan pengeluaran yang sudah dikelompokkan sesuai dengan jenisnya, disamping memuat saldo bulanan. Sedangkan al-Khithâmah Jami'ah adalah laporan keuangan yang dibuat oleh seorang akuntansi untuk diberikan kepada orang yang lebih tinggi derajatnya apabila alKhithâmah Jami'ah disetujui orang yang menerima laporan keuangan tersebut sehingga laporan ini disebut al-Muwâfaqoh. Apabila al-Khithâmah itu ditolak karena sebab data-datanya yang dimuat terdapat perbedaan maka dinamakan muhâsabah (akuntansi) saja. ${ }^{9}$

\section{Islamic Social Responsibility dalam Pandangan Islam}

Konsep tanggung jawab dalam Islam lebih menekankan bentuk ketakwaan umat manusia kepada Allah Swt dalam dimensi perusahaan. Nilainilai Islam yang dibawa oleh Nabi Muhammad Saw dapat digunakan sebagai landasan tanggung jawab sosial perusahaan sama seperti halnya

${ }_{9}$ Arfan Ikhsan, Sukma Lesmana dan Atma Hayat, Teori Akuntansi..., h. 8. 
pada perusahaan konvensional ${ }^{10}$. Nilai-nilai Islam memiliki hubungan yang relevan dan memiliki kontribusi terhadap konsep tanggung jawab sosial yang telah berkembang hingga saat ini. Tanggung jawab sosial dari sudut pandang Islam berasal dari prinsip yang terdapat dalam Alquran. Farook menyimpulkan tiga prinsip yang mendasari tanggung jawab sosial di dalam Islam, yaitu:11

\section{Perwakilan}

Prinsip perwakilan menjelaskan bahwa manusia adalah perwakilan dari Allah di bumi. Hal ini tercermin dari firman Allah didalam Alquran surat al-Baqarah [2]: 30.Ayat lain yang prinsip perwakilan menjelaskan konsep yang sama yaitu manusia dipercaya untuk mengelola dan menjaga segala kepunyaan Allah di muka bumi. Hal inilah yang juga terdapat pada surat al-An 'âm [6]: 165.

2. Tanggung jawab terhadap Allah Swt

Prinsip kedua yaitu tanggung jawab kepada Allah. Prinsip ini menggambarkan bahwa setiap manusia akan dimintai pertanggungjawaban pada hari pembalasan atas apa yang dilakukannya di dunia. Tanggung jawab kepada Allah merupakan dasar bagi semua tindakan dari umat muslim, begitupun dengan organisasi Islam. Beberapa ayat dalam Alquranmenerangkan prinsip tersebut, dua diantaranya yaitu surat alZalzalah [99]: 7 dan surat an-Nisa [4]: 86.

3. Anjuran kepada yang ma'ruf dan mencegah yang mungkar

Prinsip ketiga yang merangkum dua prinsip sebelumnya adalah menyuruh kepada yang ma'ruf dan mencegah kemungkaran. Tanggung jawab ini melingkupi semua aspek dalam kehidupan umat muslim. Prinsip inilah yang terdapat dalam surat at-Taubah [9]: 71.

${ }^{10} \mathrm{C}$. Siwar dan M. T. Hossain "An analysis of Islamic CSR concept and th opinion of Malaysian managers". Management of Environmental Quality: An International Journal, 2009, h. 292.

${ }^{11}$ Sayd Farook, "Social Responsibility for Islamic Financial Institutions: Laying Down a Framework". Journal of Islamic Economics, Banking and Finance, 2009, h. 70.

\section{Pendekatan Mashlahah dan Maqâshid al-Syarî̀ah sebagai Prinsip Pelaksanaan Islamic Social Responsibility}

Islam sangat menekankan pentingnya mempertimbangkan kepentingan umum dan itu konsisten dengan tujuan serta dasar pemikiran dari syariat yang mempromosikan mashlahah (manfaat) dan memukul mundur yang membahayakan rakyat. Al-Khawarizmi mendefinisikan mashlahah sebagai pelestarian maqâshid al-syarî̉ah. ${ }^{12}$ Menurut al-Ghazâli, maslahah didefinisikan sebagai ekspresi untuk akuisisi manfaat dan tolakan dari bahaya dengan pelestarian tujuan dari syariah. ${ }^{13}$ Sementara Ibn Ashur menggambarkan maslahah sebagai tertinggi kebenaran dan kebaikan tindakan yang selalu memberikan manfaat kepada masyarakat atau individu. ${ }^{14}$ Prinsip penciptaan mashlahah dalam pelaksanaan tanggung jawab sosial korporasi bertujuan untuk menegakkan dan memelihara kemaslahatan serta menolak mafsadah (keburukan). ${ }^{15}$ Syariah Islam tidak hanya sekedar bimbingan untuk beribadah tetapi berisi bimbingan dan petunjuk untuk seluruh aspek kehidupan.

Syariah bersifat tetap sebab syariah adalah prinsip-prinsip agama tidak dapat diubah. Syariah menjadi suatu sistem etika dan nilai-nilai yang mencakup seluruh aspek kehidupan, menjadi dasar dan sarana utama dalam menyesuaikan diri dengan perubahan. Ini mencerminkan pandangan umum Islam yang menjadi panduan lengkap dan meyeluruh dalam semua aspek kehidupan, baik individu maupun sosial, dunia dan akhirat. Secara riil, pelaksanaan aktivitas ekonomi, sosial dan politik merupakan aspek yang tidak dapat dipisahkan dari nilai, etika, dan tujuan syariat Islam yang mencakup pelaksanaan tanggung

${ }^{12}$ Al-Shawkani, Irshsad al-fuhul, (Beirut: Mu'assasat alKutub al-Thaqafiyyah.1995), Ed.7, h. 79.

${ }^{13}$ Abu Hamid Muhammas ibn Muhammad al- Ghazâli, AlMustafa, (Beirut: Dar Ihya al-Turâth al-`Arabi, 1997), h. 89.

${ }^{14}$ Syahiza Arsad, Roshima Said, Haslinda Yusoff, Yusuf Haji-Othman dan Rahayati Ahmad."The Relationship between Islamic Corporate Social Responsibilityand Firm's Performance: Empirical Evidence from Shari'ah Compliant Companies". European Journal of Business and Management, Vol.6, No.36, 2014, h. 164.

15 Muhammad Yasir Yusuf, Islamic Corporate Social Responsibility (I-CSR) pada lembaga keuangan syariah: Teori dan Praktik. (Depok: Kencana, 2017), h.91. 
jawab sosial suatu korporasi terhadap lingkungan dan masyarakat di sekitarnya.

Ada dua acuan pemeliharaan kemaslahatan atau maqâshid al-syarîah yang dapat dijadikan landasan dasar dalam melaksanakan aktivitas dan tanggung jawab sosial. Pertama, sisi positif yaitu dapat memelihara hal-hal yang menjamin terciptanya kemaslahatan. Kedua, sisi negatif yaitu menolak dan menyingkirkan semua kemungkinan mafsadah yang terjadi atau yang akan terjadi dalam operisonal aktivitas pelaksanaan tanggung jawab sosial suatu korporasi. ${ }^{16}$

Imam Al-Shatibi mengklasifikasikan maslahah dalam tiga kategori, yaitu dharuriyat (yang penting), hajiyat (komplementer) dan tahsiniyat (hiasan). ${ }^{17}$ Menurut Dusuki dan Nurdianawati, tiga kategori ini mencerminkan tingkat yang berbeda dari tanggung jawab pemenuhan dan pengambilan keputusan serta dapat diterapkan dalam dimensi aktivitas tanggung jawab sosial. ${ }^{18}$. Dharuriyat adalah tingkat terendah dan tanggung jawab yang paling dasar yang harus dipenuhi untuk melestarikan dan melindungi kebutuhan penting stakeholders yaitu agama (dîn), kehidupan (nafs), kecerdasan ('aql), keturunan (nasl) dan properti (mâl). Setelah tingkat dharuriyat telah terpenuhi, perusahaan harus berusaha untuk meningkatkan pemenuhan mereka tanggung jawab sosial ke tahap yang lebih baik yang hajiyat. Islam juga memotivasi muslim untuk terus dan konsisten berjuang untuk unggul dan mendapatkan kenikmatan serta pahala yang lebih baik dari Allah. ${ }^{19}$ Sementara di tingkat tahsiniyat, suatu korporasi diharapkan untuk melaksanakan kegiatan tanggung jawab sosial mereka yang dapat menyebabkan peningkatan dan mencapai kesempurnaan hidup masyarakat. Ketiga kategori maslahah saling tergantung antara satu sama lain dan dapat membantu untuk memecahkan banyak masalah kepada perusahaan itu sendiri dan juga untuk negara atau negara.

\footnotetext{
${ }^{16}$ Al-Shawkani, Irshsad al-fuhul..., h. 45.

${ }^{17}$ A. W. Dusuki and I.A. Nurdianawati, "Maqasid al-Shari'ah, Maslahah and Corporate Social Responsibility", The American Journal of Islamic Social Sciences, Vo. 24, No. 1, 2007, h. 32.

${ }^{18}$ A. W. Dusuki and I.A. Nurdianawati, "Maqashid alShari'ah..., h. 32.

${ }^{19} \mathrm{H}$. Mohd Kamal, Worldview Orientation and Ethics: A Muslim Perspective, In Ethics in Business and Management Islamic and Mainstream Approcahes, (London: Asean Academic Press, 2002), h. 85.
}

Perusahaan perlu terlibat dan mengelola kegiatan mereka sesuai dengan prioritas dan tidak dapat fokus pada mencapai hiasan sementara membahayakan kebutuhan penting (dharuriyat) orang. Sementara, maqâshid alsyarîah harus ditegakkan setiap saat ketika melakukan kegiatan (baik itu untuk pribadi atau publik). Selanjutnya, dalam rangka memastikan klien mereka telah terpenuhi kebutuhan spiritual dan duniawi yang pada akhirnya berefek pada berkah dari Allah Swt. ${ }^{20}$

Pada dasarnya, Islam bertujuan untuk melindungi umat manusia sehingga maslahah dan maqâshid al-syarîah memberikan unsur pedoman yang relevan dengan etika dan kerangka tata kelola perusahaan yang baik. Karena itu, komitmen harus diambil dalam rangka untuk mencapai manfaat dan menghindarkan bahaya bagi umat manusia. Akibatnya, pelaporan tanggung jawab perusahaan yang berbasis Islami juga akan menggambarkan citra perusahaan yang berbasis syariah. ${ }^{21}$

\section{Korelasi Akuntabilitas dengan Muamalah}

Muamalah merupakan medan hidup yang sudah tersentuh oleh tangan-tangan manusia sejak zaman klasik, bahkan zaman purbakala. Setiap orang membutuhkan harta yang ada di tangan orang lain. Hal ini membuat manusia berusaha membuat beragam cara pertukaran, bermula dengan kebiasaan melakukan tukar menukar barang (barter), berkembang menjadi sebuah sistem jual-beli yang kompleks dan multidimensional. Islam mungkin menjadi satusatunya agama yang memberikan nilai positif dan tinggi pada kegiatan ekonomi yang sah. Laba dari kegiatan ekonomi dianggap menjadi "Rahmat" dari Allah. ${ }^{22}$ Dalam ayat tersebut ditunjukkan bahwa Islam adalah agama pedagang, bukan agama padang pasar petani. ${ }^{23}$

${ }^{20}$ S. Ruslinda, "Realising Maqasid Al-Shariah in Islamic Financial Planning", The 4E Journallslamic Finance, (JanuaryMarch, 2011) h. 13-17.

${ }^{21}$ Syahiza Arsad, Roshima Said, Haslinda Yusoff, Yusuf Haji-Othman dan Rahayati Ahmad.“"The Relationship...,h. 165.

${ }^{22}$ A.A. Islahi, Economic Concept of Ibn Taymiya, (London: Islamic Foundation, 1988), h. 151.

${ }_{23}$ W. Montgomery Watt, "The Influennce of Islam on Medieval Europe (Chichukai Sekai no Isurama)", terj. Wataru Miki, (Tokyo: Chikuma Shobo, 1972), h.31 
Rasulullah sendiri adalah pemimpin kafilah dagang milik Khadijah, yang kemudian menjadi istrinya. ${ }^{24}$ Mekah tempat Islam diturunkan kepada Muhammad merupakan kota pusat perdagangan dan perbankan.

Upaya untuk mengamalkan dan mensyiarkan Islam dan perdagangan yang jujur sebagai bagian dari jihad. Memang bagi seorang muslim, dibutuhkan syarat dan prasyarat yang lebih banyak untuk menjadi pengelola modal yang berhasil karena seorang muslim selalu terikat, yakni terikat dengan kode etik ilmu perdagangan, dengan aturan syariat Islam, dan dengan hukum-hukumnya yang komprehensif. Oleh sebab itu, tidak selayaknya seorang muslim memasuki dunia bisnis dengan pengetahuan kosong terhadap ajaran syariat, terutama dalam mengenai akuntabilitasnya. Hal yang demikian itu merupakan sasaran empuk ambisi setan pada diri manusia untuk menjerumuskan seorang muslim dalam kehinaan.

Muamalah sangat erat dengan perekonomian Islam. Ini akan tampak bila kita melihat salah satu bagiannya, yaitu dunia bisnis perniagaan, dan khususnya level menengah ke atas. Dunia bisnis utamanya dalam tingkat korporasi nasional maupun multinasional ini membutuhkan kepekaan yang tinggi, yakni feeling yang kuat dan keterampilan yang matang serta pengetahuan yang komplit terhadap berbagai epistimologi terkait, seperti akuntansi, perdagangan, bahkan perbankan dan sejenisnya. Bila ditinjau lebih dalam, Akuntansi Islam adalah teori yang menjelaskan bagaimana mengalokasikan sumber-sumber yang ada secara adil bukan pelajaran tentang akuntansi itu ada. Shahata menjelaskan bahwa akuntansi Islam adalah "Postulat, standar, penjelasan dan prinsip akuntansi yang menggambarkan semua hal...karenanya secara teoritis akuntansi memiliki konsep, prinsip dan tujuan Islam dan semua ini secara serentak berjalan bersama bidang-bidang ekonomi, sosial, politik, ideologi, manajemen, akuntansi, dan lain-lain. Kesemuanya ini adalah paket yang tidak bisa dipisah". ${ }^{25}$

${ }^{24}$ J. Do Somogyi, "The in the Quran and Hadith", Muslim Word, Vol 52, 1962, h.110.

${ }^{25}$ Shauqi Isumail Shahata, Financial Accounting from the Islamic point of view (nazariya al-muhasaba al-maliya min
Islam sebagai suatu ajaran yang meliputi aspek akuntansi mengatur masyarakat dalam konsep perniagaan yang cukup detail sebagaimana yang tercantum dalam Alquran dan sunah. Akuntansi dari pandangan Islam juga tergantung pada tujuan masyarakat Islam yang sempurna. Demi terpenuhi kesempurnaan substansi akuntansi, Alquran juga memberikan penekanan pada pertanggungjawaban atau "accountability". Hal ini dapat dilihat dalam surat al-Baqarah [2]: 282, yang menyebutkan bahwa kewajiban bagi orang beriman adalah menulis setap transaksi not completed atau non cash. Ayat tersebut jelas sekali bertujuan untuk menegakkan keadilan dan kebenaran. Artinya, perintah ini ditekankan pada kepentingan accountability agar pihakpihak yang terlibat dalam transaksi tersebut itu tidak dirugikan, tidak menimbulkan konflik dan adil sehingga perlu saksi. Alquran melindungi kepentingan masyarakat demi terciptanya keadilan dan kebenaran sehingga tekanan yang timbul dari akuntansi bukan pengambilan akuntansi tetapi pertanggungjawaban.

Ternyata disiplin ilmu akuntansi dengan sifat decision making tools-nya kembali ke awal, kembali ke basic nature. Artinya, pertanggungjawaban dan hal inilah yang sesuai dengan konsep Islam. Serta adanya kecenderungan munculnya "convergency" antara konsep kapiltalis barat yang sudah terkoreksi dengan konsep Islam. Pada akhirnya inilah substansi the beauty of Islam dalam konsep pertanggungjawaban.

\section{Diskursus Implementasi Islamic Social Reporting}

Kerangka syariah ISR dicetuskan oleh Ross Haniffa pada tahun 2002 dalam tulisannya yang berjudul"Social Reporting Disclosure: Anlslamic Perspective". Lebih lanjut, ISR dikembangkan secara lebih ekstensif oleh Rohana Othman, Azlan MdThani, dan Erlane K Ghani pada tahun 2009 di Malaysia. Saat ini, ISR masih terus dikembangkan oleh peneliti-peneliti selanjutnya.

Implementasi ISR pada dasarnya tidak dapat dipisah unsur ketaudidan dalam kerangka syariah. Kerangka ini akan menghasilkan aspek-aspek

manzur islami), (Cairo:al-zahra al a'lam al-arabi, 1988),h. 9 
material, moral, dan spiritual dalam pelaporan ISR perusahaan. ${ }^{26}$ Tauhid dalam kerangka syariah merupakan pondasi dari ajaran Islam dan menunjukkan bahwa alam semesta ini satu dan bahwa kesatuan seluruh isi dan tatanannya ekonomi, politik, sosial, maupun lingkungan di alam semesta ini diikat oleh sebuah inti. Inti itu adalah Tauhid (Q.S.Thaha [20]: 53-54). Wujud dari tauhid adalah syahadat. Syahadat merupakan rukun Islam dan pengakuanakan keesaan Allah Swt yang diyakini dalam hati, dibenarkan dengan lisannya, dan dibuktikan dengan amal perbuatan nyata. Orang yang mengucapkan syahadat akan menerima konsekuensi dari tauhid berupa kewajiban untuk tunduk terhadap segala hukum Allah Swt yang bersumber dari Alquran, hadis, fikih, dan sumber lainya seperti qias, ijtihad, dan ijma. Tujuan dari hukum syariah ini adalah untuk menegakkan keadilan sosial dan mencapai kebahagian di dunia dan di akhirat. ${ }^{27}$

Gambar 1. Kerangka Syariah ISR

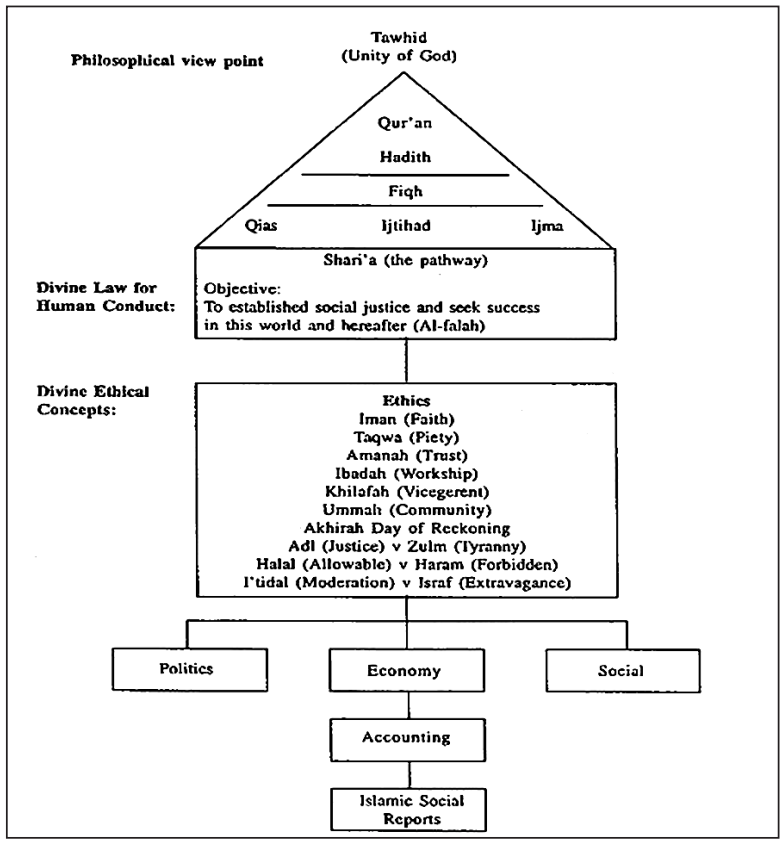

Sumber: Haniffa, 2002

Hukum syariah ini akan menjadi dasar terbentuknya konsep etika dalam Islam. Secara umum, etika dalam Islam terdiri dari sepuluh etika yang mengatur hubungan manusia dengan Allah Swt, manusia dengan manusia, dan manusia dengan alam semesta. Kesepuluh konsep etika

\footnotetext{
${ }^{26}$ Shauqi Isumail Shahata, Financial Accounting..., h. 9.

${ }^{27}$ R. Haniffa, "Social Reporting Disclosure ..., h. 134
}

tersebut adalah iman, takwa, amanah, ibadah, khilafah, ummah, keyakinan akan datangnya hari kiamat, 'adil dan zulm, halâl, dan haram, serta i'tidal, dan ishraf. Etika inilah yang nantinya menjadi landasan manusia dalam melakukan aktivitas politik, ekonomi, dan sosial. ISR berada pada lingkup aktivitas ekonomi, khususnya aspek akuntansi. Dengan demikian, ISR merupakan bagian dari kerangka syariah. ISR adalah standar pelaporan kinerja sosial perusahaan-perusahaan yang berbasis syariah.

Untuk mengukur sejauh mana implementasi ISR, metode analisis isi digunakan untuk mengukur informasi Islam diungkapkan dalam laporan tahunan perusahaan yang terdaftar yang berbasis syariah. Analisis isi/muatan yang dipilih sebagai metode yang paling umum digunakan untuk memeriksa bahan tertulis yang terdapat dalam laporan tahunan ${ }^{28}$. Komponen pengungkapan ISR adalah item-item pengungkapan yang digunakan sebagai indikator dalam pelaporan kinerja sosial institusi bisnis syariah. Haniffa membuat lima tema pengungkapan indeks ISR, yaitu tema pendanaan dan investasi, tema produk dan jasa, tema karyawan, tema masyarakat, dan tema lingkungan hidup. ${ }^{29}$ Kemudian dikembangkan oleh Othman et al., dengan menambahkan satu tema pengungkapan yaitu tema tata kelola perusahaan..$^{30}$

\section{a. Pendanaan dan Investasi}

Informasi yang akan diungkapkan adalah apakah sumber pembiayaan dan investasi yang bebas riba dan spekulatif (gharâr) karena hal ini sangat dilarang dalam Islam ${ }^{31}$ sebagaimana disebutkan dalam Q.S. Al-Baqarah [2]:278-279. Terkait ayat ini, tafsir Ibnu Katsir menyatakan bahwa Allah Swt memerintahkan hamba-hambaNya sekaligus melarang mereka mengerjakan halhal yang dapat mendekatkan kepada kemurkaanNya serta menjauhkan dari kemurkaan-Nya dan

\footnotetext{
${ }^{28}$ Rohana Othman and A. M. Thani, "Islamic social reporting of listed companies in Malaysia", International Business \& Economics Research Journal, Vol 9, No. 4, 2010, h. 140.

${ }^{29}$ R. Haniffa, "Social Reporting Disclosure ...: 137.

30 Rohana Othman and A. M. Thani, "Islamic social reporting..., h. 9.

${ }^{31}$ Rohana Othman and A. M. Thani, "Islamic social reporting ..., h.137.
} 
mejauhkan dari keridhaan-Nya. Beriman kepada syariat Allah Swt yang telah ditetapkan kepada kalian berupa penghalalan jual beli, pengharaman riba, dan lain sebagainya. ${ }^{32}$ Ayat ini merupakan peringatan keras dan ancaman yang sangat tegas bagi orang yang masih tetap mempratikkan riba setelah adanya peringatan tersebut. ${ }^{33}$

Indeks Pengukuran ISR untuk tema pendanaan dan investasi meliputi pelaporan mengenai (1) kegiatan yang mengandung riba, (2) pengungkapan kegiatan yang mengandung gharar atau tidak (memastikan adanya ketidakpastian yang dilarang dalam Islam), (3) zakat, (4) kebijakan atas keterlambatan pembayaran piutang dan penghapusan piutang tak tertagih, (5) pernyataan nilai tambah perusahaan. ${ }^{34}$

\section{b. Produk dan Jasa}

Konsep produk dan jasa merupakan tanggung jawab perusahaan untuk mengungkapkan bahwa produk tersebut termasuk ke dalam kategori yang dilarang, yakni meliputi aktivitas perjudian dan hiburan, transaksi senjata, hewan-hewan haram (babi), dan minuman keras. Orang Islam benar-benar peduli dengan status halal dari suatu produk/jasa. ${ }^{35}$ Bahkan, hal ini didasari oleh hadis sebagai berikut: Sesungguhnya Allah dan RasulNya telah melarang penjualan anggur (minuman keras), bangkai, babi dan berhala (HR. Bukhari). ${ }^{36}$

Indeks Pengukuran ISR untuk tema produk dan jasa meliputi pelaporan mengenai (1) Produk/ kegiatan ramah lingkungan, (2) kehalalan produk, (3) keamanan, dan kualitas produk, (4) pelayanan pelanggan. ${ }^{37}$

${ }^{2}$ Ibnu Katsîr, Lubâbut tafsir min Ibnu Katsîr, diterjemahkan tafsir Ibnu Katsir oleh M. Abdul Ghoffar E.M., Abdurrahim Mu'thi, Abu Ihsan Al-Atsari; pengedit, M Yusuf Harun et al, (Bogor: Pustaka Imam Asy-Syafi-I, 2004), h. 556.

33 Ibnu Katsîr, Lubâbut tafsir min Ibnu Katsîr..., h. 556

${ }^{34}$ Bayu Tri Cahya, "Islamic Social Report: Ditinjau Dari Aspek Corporate Governance Strength, Media Exposure Dan Karakteristik Perusahaan Berbasis Syariah Di Indonesia Serta Dampaknya Terhadap Nilai Perusahaan", Disertasi, Medan: Program Doktor Ekonomi Syariah Pascasarjana UINSU, 2017, h. 141.

${ }^{35}$ R. Haniffa, "Social Reporting Disclosure ..., h.140.

${ }^{36}$ Imam Abi al-Husain Muslim bin al-Hajjaj al-Qusyairi an-Naisaburiy, Shahih Muslim, (Beirut: Dar al-Kitab alImaniyah,1995), Juz 5, h. 35.

37 Bayu Tri Cahya, "Islamic Social Report..., h.141.

\section{c. Karyawan}

Masyarakat Islam perlu tahu jika perusahaan dikelola secara adil terkait karyawan seperti informasi mengenai upah, sifat pekerjaan, jam kerja per hari, cuti tahunan, kesehatan dan kesejahteraan, kebijakan mengenai hal-hal keagamaan seperti waktu shalat dan tempat, pendidikan dan pelatihan dukungan kepada karyawan, kesempatan yang sama dan lingkungan kerja. ${ }^{38}$ Pengusaha diharapkan untuk bermurah hati kepada karyawan mereka. Hhal ini berdalil dengan hadis dari Abdullah bin Umar RA bahwasanya Rasulullah saw yang berbunyi "Berikan kepada seorang pekerja upahnya sebelum keringatnya kering" (HR Ibnu Majah). ${ }^{39}$ Hadis sahih ini berupa perintah yang wajib ditunaikan para majikan. Haram hukumnya menangguhkan gaji pekerja tanpa alasan yang syar'i.

Indeks pengukuran ISR untuk tema karyawan meliputi pelaporan mengenai (1) jam/waktu kerja, (2) hari libur dan cuti karyawan, (3) tunjangan karyawan, (4) remunerasi, (5) pendidikan dan pelatihan bagi karyawan, (6) kesempatan dan kesetaraan gende, (7) keterlibatan karyawan dalam diskusi/pengambilan keputusan, (8) kesehatan dan keselamatan kerja, (9) lingkungan kerja, (10) karyawan dari kelompok disabilitas, (11) karyawan muslim boleh menjalankan ibadah dan puasa, (12) tempat ibadah yang memadai. ${ }^{40}$

\section{d. Masyarakat}

Kebutuhan umat atau masyarakat luas dapat dicapai melalui sadaqah (amal), wakaf (trust) ${ }^{41}$ dan qard hassan (pinjaman tanpa profit). Perusahaan-perusahaan harus mengungkapkan perannya dalam meningkatkan pembangunan ekonomi dan mengatasi masalah sosial dari masyarakat ketika mereka beroperasi. ${ }^{42}$ Seperti yang tercantum dalam Alquran Q.S. Al Baqarah [2]: 271, yang didasarkan atas penafsiran Ibnu Katsir mengenai ayat tersebut menyatakan bahwa

\footnotetext{
${ }^{38}$ Rohana Othman and A. M. Thani, Islamic Social Reporting..., h.138.

${ }^{39}$ Muhammad Abi Abdillah, Sunan ibnu Majjah, (Istanbul: Dar Da'wah, 1992), h. 722.

${ }^{40}$ Bayu Tri Cahya, Islamic Social Report..., h.141.

${ }^{41}$ R. Haniffa, Social Reporting Disclosure..., h.140.

${ }^{42}$ B. Maali,P. Cassonand C Napier, "Social Reporting by Islamic Banks", ABACUS, Vol.42, No. 2, 2006, h. 270.
} 
di dalam ayat tersebut terdapat dalil yang menunjukkan bahwa memberi sedekah secara sembunyi-sembunyi itu lebih baik jauh dari sikap riya'. Namun, menampakkan sedekah bisa saja dilakukan jika akan mendatangkan kemaslahatan dan mejadi contoh bagi orang lain sehingga hal itu menjadi afdhal. ${ }^{43}$

Indeks pengukuran ISR untuk tema masyarakat meliputi pelaporan mengenai 1) sedekah, donasi, sumbangan 2) sukarelawan dari kalangan karyawan, 3) pemberian beasiswa, 4) pemberdayaan lulusan, 5) pengembangan kepemudaan, 6) peningkatan kualitas hidup masyarakat miskin, 7) kepedulian terhadap anak, 8) kegiatan amal, 9) mensponsori acara berbagai bidang (kesehatan, budaya, dan lain-lain). ${ }^{44}$

\section{e. Lingkungan Hidup}

Perusahaan tidak seharusnya terlibat dalam setiap jenis kegiatan yang mungkin menghancurkan atau merusak lingkungan. Dengan demikian, informasi yang terkait dengan penggunaan sumber daya dan program yang dilakukan untuk melindungi lingkungan harus diungkapkan. 45 Alquran mengutuk eksploitasi lingkungan seperti yang termaktub dalam firman Allah dalam Q.S. ArRûm [30]: 41. Dalam tafsir Ibnu Katsir, Abul'Aliyah berkata "Barang siapa yang berlaku maksiat kepada Allah di muka bumi, berarti dia telah berbuat kerusakan di dalamnya karena kebaikan bumi dan langit adalah dengan ketaatan". ${ }^{46}$ Oleh karena itu, jika hudud ditegakkan, niscaya manusia dan mayoritas merekaakan menahan diri dari melakukan hal-hal yang diharamkan. Bilamana maksiat-maksiat ditinggalkan, maka hal tesebut menjadi sebab tercapainya berbagai berkah dari langit dan bumi. ${ }^{47}$

Indeks pengukuran ISR untuk tema lingkungan meliputi pelaporan mengenai (1) konservasi lingkungan, (2) kegiatan mengurangi efek pemanasan global, (3) pendidikan mengenai lingkungan, (4) pernyataan verifikasi independen/

${ }^{43}$ Ibnu Katsir, "Lubaabut tafsir min Ibnu Katsiir.., h. 539.

${ }^{44}$ Bayu Tri Cahya, "Islamic Social Report..., h. 141.

45 Rohana Othman and A. M. Thani, "Islamic Social Reporting..., h.138.

${ }^{46}$ Ibnu Katsîr, Lubâbut tafsir min Ibnu Katsîr..., h.,539.

47 Ibnu Katsîr, Lubâbut tafsir min Ibnu Katsîr ..., h.,539.. audit lingkungan, dan (5) sistem manajemen lingkungan. ${ }^{48}$

\section{e. Tatakelola Perusahaan}

Tatakelola perusahaan dalam ISR merupakan penambahan dari Othman et al., dimana tema ini tidak bisa dipisahkan dari perusahaan guna memastikan pengawasan pada aspek syariah perusahaan. ${ }^{49}$ Tata kelola perusahaan dalam perspektif Islam atau dapat diistilahkan dengan Islamic corporate governance senantiasa mengaitkan segala konsep dan tingkah-laku dalam tata kelola bisnis dengan hal-hal yang bersifat transendental dan imanen. Hal ini merupakan sebuah konsekuensi keimanan seorang muslim kepada Allah Swt. Maka dari sini kita mengenal nilai tauhid sebagai landasan atas segala keyakinan, pemikiran dan prilaku seorang muslim, termasuk dalam memahami tata kelola perusaan ini.

Salah satu prinsip yang merupakan turunan terbesar dari nilai tauhid adalah prinsip keadilan. Alquran senantiasa mendorong umatnya untuk bersikap adil dalam setiap hal, baik dalam masalah akidah, syariah, maupun akhlak sebagai konsekuensi atas keimanan dan untuk mencapai derajat ketakwaan. Sebagaimana firman Allah Swt dalam surah Al-Mâ idah [5]: 8 yang menegaskan bahwa jadilah kalian penegak kebenaran karena Allah Swt, bukan karena manusia atau mencari popularitas, dan jadilah saksi dengan adil. Maksudnya secara adil dan bukan secara curang. ${ }^{50}$ Sejalan dengan ayat tersebut, salah satu prinsip dalam pelaksanaan corporate governance adalah fairness (kesetaraan atau keadilan) yang dimaksudkan untuk menghadirkan pengelolaan perusahaan yang adil bagi setiap pihak.Jika dikaitkan dengan syariah, maka keadilan tersebut harus mencakup aspek spiritual dan material. Maka, makna adil dapat diperluas pada setiap prinsip yang terdapat dalam Corporate Governance maupun nilai-nilai lain yang dapat dimunculkan atas implementasi keadilan.

\footnotetext{
${ }^{48}$ Bayu Tri Cahya, “Islamic Social Report... ,142.

49 Rohana Othman and A. M. Thani, "Islamic social reporting ..., h. 9.

${ }^{50}$ Ibnu Katsîr, Lubâbut tafsir min Ibnu Katsîr..., h. 45.
} 
Indeks pengukuran ISR untuk tema tatakelola perusahaan meliputi pelaporan mengenai (1) status kepatuhan syariah, (2) struktur kepemilikan saham, (3) profil dewan direksi, (4) pengungkapan praktik monopoli. 5) pengungkapan praktik perkara hokum, 6) kebijakan anti korupsi. ${ }^{51}$

\section{Implementasi ISR: Ditinjau dari Hasil Riset-Riset Terdahulu}

Haniffa pada tahun 2002 dalam artikelnya yang membahas ISR menunjukkan pentingnya menjaga lingkungan di Syariah Islamiah dan menekankan konsep mizan (keseimbangan), i'tidal (moderasi) dan khilafah (tanggung jawab) untuk menjaga lingkungan dan setiap tindakan pemanfaatan lingkungan dikecam dengan kuat dalam Islam. Haniffa menyarankan perlunya penggunaan kerangka syariah Islam dalam mengembangkan pengungkapan sosial Islam untuk memenuhi tujuan akuntabilitas dan transparansi. Konsep tersebut membahas hubungan antara manusia dengan Allah, manusia dengan manusia, dan juga manusia dengan alam. ${ }^{22}$

Pelaporan sosial berbasis Islam terus berkembang dengan studi lebih lanjut oyang dilakukan oleh Rohana et al pada tahun 2009. Temuan penelitian menunjukkan bahwa ukuran perusahaan sangat signifikan dengan tingkat pengungkapan informasi sosial dalam laporan tahunan mereka. ${ }^{53}$ Penelitian ini konsisten dengan penelitian sebelumnya oleh Ousama dan Fatima pada tahun 2010.54 Rohana dan Azlan pada tahun 2010 menyelidiki lebih lanjut bahwa perusahaan syariah diharapkan mengembangkan indeks pengungkapan pelaporan sosial Islam dengan mengadopsi model yang diajukan oleh Haniffa. ${ }^{55}$

Maali et al pada tahun 2006 juga berusaha untuk menyelidiki pengaruh Islam terhadap pelaporan sosial dan mengembangkan se-

\footnotetext{
${ }^{51}$ Bayu Tri Cahya, "Islamic Social Report... ,142.

${ }^{52}$ R. Haniffa,"Social Reporting Disclosure..., h.129.

53 Rohana Othman, A. Md. Thani, dan E.K. Ghani. "Determinants of Islamic Social Reporting...,h. 5.

${ }^{54}$ A. Ousamaand A. Fatima, "Voluntary Disclosure by Shariah Approved Companies: an Exploratory Study. Journal of Financial Reporting and Accounting," Vol.8, Np. 1, 2010, h. 36.

55 Rohana Othman and A. M. Thani, "Islamic social reporting..., h. 135
}

perangkat patokan pengungkapan sosial kepada bank-bank Islam. Temuan menunjukkan bahwa pelaporan social berlandaskan konsep kosnep Islamic masih belum sesuai dengan ekspektasi. ${ }^{56}$ Hal ini juga konsisten dengan temuan oleh Farook S, Lanis R, pada tahun 2007 yang mengukur tingkat pengungkapan sosial dari 47 bank syariah yang beroperasi di 14 negara. ${ }^{57}$

Studi empiris lain, yakni Kamla dan Hussain pada tahun 2010. Keduanya menyelidiki laporan oleh sepuluh bank syariah yang memusatkan perhatian pada peran peran keadilan sosial dalam masyarakat di mana bisnis dijalankan. Mereka mengeksplorasi tema terkait dengan keadilan sosial apakah ada atau tidak hadir dari laporan tahunan dan situs web mereka. Studi ini menunjukkan bahwa pengungkapan oleh bank-bank Islam yang dieksplorasi tidak banyak memberi kontribusi dan perhatian pada skema atau inisiatif apapun untuk menghilangkan kemiskinan atau mempromosikan keadilan sosial di masyarakat. ${ }^{58}$

Harahap dan Hassan pada tahun 2010 lebih jauh menjelajahi tujuh bank syariah di tujuh negara dengan menggunakan model yang disarankan oleh Haniffa dan Hudaib (2007). Hasilnya menemukan bahwa hanya sedikit bank tersebut yang menunjukkan lebih banyak informasi dan lebih transparan kepada masyarakat mereka. ${ }^{59}$ Othman et al (2010) dalam penelitiannya ISR Of Listed Companies In Malaysia menunjukkan hasil bahwa Indeks pengungkapan tingkat ISR dianggap minim sehingga menunjukkan kurangnya transparansi dalam pengungkapan sehubungan dengan nilai-nilai Islam meskipun fakta dari konsep akuntabilitas sosial di bawah Islam adalah terkait dengan prinsip pengungkapan penuh. ${ }^{60}$

${ }^{56}$ B. Maali, P. Casson, and C. Napier, "Social Reporting by Islamic Banks", ABACUS, Vol. 42, No. 2, 2010, h. 66.

${ }^{57}$ S. Farook, M. Kabir Hassan, M and R. Lanis," Determinants of corporate social responsibility disclosure: the case of Islamic banks", Journal of Islamic Accounting and Business Research,Vol. 2, No. 2, 2011, h. 114.

${ }^{58}$ R. Kamla and H. G. Rammal,"Social reporting by Islamic banks: does social justice matter? Accounting, Auditing and Accountability Journal”, Vol. 26, No. 6, 2013, h. 911.

${ }^{59} \mathrm{~A}$. Hassan and S. Syafri Harahap,"Exploring corporate social responsibility disclosure: the case of Islamic banks", International Journal of Islamic and Middle Eastern Finance and Management, Vol. 3, No. 3, 2010, h. 203.

${ }^{60}$ Rohana Othman and A. M. Thani, "Islamic social 
Selanjutnya Fitria dan Hartanti pada tahun 2010 meneliti terkait Islam dan tanggung jawab sosial menunjukkan bahwa Lembaga perbankan konvensional pada umumnya mendapat skor yang lebih tinggi dibandingkan dengan lembaga perbankan syariah. ${ }^{61}$

Sofyani et al, pada penelitiannya tahun 2012 yang melihat kinerja perbankan Islam di beberapa negara hasil risetnya menunjukkan bahwa kinerja sosial train-average perbankan Islam di Malaysia lebih tinggi dari pada di Indonesia. ${ }^{62}$ Walaupun begitu kinerja sosial sosialnya tergolong dalam kinerja yang cukup baik. Sedangkan pada penelitian Sofyani pada tahun 2014, aktivitas sosial perbankan Islam tertinggi adalah di Malaysia, kedua di Indonesia dan terendah di Saudi Arabia. ${ }^{63}$

Penelitian lain yang dilakukan baru-baru ini lebih banyak untuk penelitian dan pengujian empiris untuk fokus secara kuantitatif daripada kualitatif. ${ }^{64}$ Di lain sisi penelitian Arsad et altahun 2014menunjukkan bahwa tingkat pengungkapan Islamic CSR secara keseluruhan masih cukup rendah dan masih kurang menyentuh nilainilai dan prinsip-prinsip Islam. Hasilnya adalah konsisten dengan penelitian sebelumnya dimana ditemukan bahwa ada hubungan yang signifikan antara pengungkapan Islamic CSR dan kinerja perusahaan. ${ }^{65}$ Penelitian Saridona dan Cahyandito tahun 2015 dari hasil analisisnya menunjukkan bahwa kinerja sosial bank syariah Indonesia,

reporting..., h. 36 .

${ }^{61}$ Soraya Fitria dan Dwi Hartanti, Islam Dan Tanggung Jawab Sosial:"Studi Perbandingan Pengungkapan Berdasarkan Global Reporting Initiative Indeks Dan Islamic Social Reporting Indeks". Purwokerto: Simposium Nasional Akuntansi 13, 2010, h. 1.

${ }^{62}$ H. Sofyani, I. Ulum, Daniel Syam dan Sri Wahyuni L, "Islamic Social Reporting Index Sebagai Model Pengukuran Kinerja Sosial Perbankan Syariah (Studi Komparasi Indonesia Dan Malaysia)", Jurnal Dinamika Akuntansi Vol. 4, No. 1, Maret 2012, h. 36.

63 Hafiez Sofyani, "Islamic Social Reporting Perbankan Syariah Di Indonesia, Malaysia Dan Saudi Arabia: Sebuah Studi Menggunakan Anova", Summary Research, Fakultas Ekonomika dan Bisnis. Universitas Gadjah Mada, Yogyakarta, 2014, h. 8.

64 Penelitian penelitian yang dimaksudkan diatas merupakan penelitian yang dilakukan oleh Aziah Abu Kasim 2012; Darus et al 2013; Alsaadi, Jaafar, dan Ebrahim 2013; Zainal et al 2013; Widiawati dan Raharja 2012; Ayu et al 2013; Khoirudin 2013; Putri dan Yuyetta 2014; Indrawaty dan Wardayati 2016.

${ }^{65}$ Syahiza Arsad, Roshima Said, Haslinda Yusoff, Yusuf HajiOthman dan Rahayati Ahmad, "The Relationship..., h. 161-174. yang terungkap dalam laporan tahunan 2013, dalam kategori 'baik'. ${ }^{66}$ Kinerja sosial pada penelitian ini didasarkan pada Pelaporan Index Sosial Islam. Secara umum, Bank berbasis Islam di Indonesia, sudah fokus pada kegiatan sosial, termasuk bantuan bagi masyarakat istimewa, program pendidikan seperti perbaikan alat pendidikan, dan juga perawatan kesehatan. Sayangnya, hanya sedikit bank-bank tersebut yang memiliki kepedulian terhadap kelestarian lingkungan.

Cahya et al, dalam penelitiannya pada tahun 2017 menunjukkan bahwa sepanjang tahun penelitian 2012 sampai 2015 pengungkapan item-item ISR berada pada tingkat $64-74 \%{ }^{67}$ Hasil ini walau belum menunjukkan hasil yang optimal tetapi tidak terlalu mengecewakan untuk pengungkapan ISR oleh perusahaanperusahan yang termasuk dalam Jakarta Islamic Index. Berdasar atas penelitan-penelitian terdahulu dapat diketahui bahwa pada dasarnya pengungkapan laporan tahunan entitas bisnis syariah sudah cukup akuntabel, tetapi dari unsur pengungkapan yang memperhatikan indeks ISR masih belum ada satupun yang mencapai hasil yang benar benar maksimal. Apabila mengacu pada konsep Social Report Continuum yang dikembangkan Dusuki tahun 2008, maka penulis menyimpulkan bahwa implementasi ISR masuk dalam kategori strategic (artinya belum sepenuhnya menyentuh kategori taqwa-centric). Entitas bisnis dalam kategori ini sudah memenuhi tanggung jawab sosial mereka, termasuk tanggung jawab filantropi atau altruistik seperti memberikan kontribusi sukarela kepada masyarakat, memberikan waktu dan uang untuk pekerjaan baik yang mereka anggap dapat memberi manfaat bagi perusahaan dalam jangka panjang, melalui publisitas dan niat baik yang positif sehingga kedepannya dapat

${ }^{66}$ Resa Saridona, dan Cahyandito,Martha Fani, "Social Performance of Indonesia Islamic Banking: Analysis of Islamic Social Reporting Index", International Conference on Economics and Banking, 2015, h. 194.

67 Bayu Tri Cahya, A. Nuruddin dan A. Ikhsan, "Islamic Social Reporting: From the Perspectives of Corporate Governance Strength, Media Exposure and the Characteristics of Sharia Based Companies in Indonesia and its Impact On Firm Value" IOSR Journal of Humanities And Social Science (IOSRJHSS,) Vol. 22, Issue 5, Ver. 10, May. 2017, h. 76. 
meningkatkan reputasi perusahaan dan pada akhirnya mengamankan keuntungan jangka panjangnya. ${ }^{68}$

\section{Penutup}

Sistem akuntansi Islam pada perkembangannya saat ini menunjukkan kinerja yang lebih baik dari sistem akuntansi lainnya. Islam memiliki perspektif tersendiri berkaitan dengan pertanggungjawaban (akuntabilitas) karena dalam Islam semua yang dititipkan kepada manusia adalah amanah, konsep amanah merupakan bagian universal yang kemudian dituntunkan menjadi pertanggunjawaban (akuntabilitas). Akuntabilitas bagi pemilik harta dalam Islam meliputi tidak hanya penggunaan tetapi juga bagaimana peroses memilikinya yang "hallâlan thayyibah" (yang halal lagi baik) secara horizontal, dan secara vertikal pertanggungjawaban tersebut juga meliputi kecintaan seseorang tehadap aktiva yang dimilikinya. Akuntabilitas atau amanah sebenarnya bukan konsep baru dalam Islam yang meliputi pertanggungjawaban kepada yang memberi amanah kepada Allah Swt. Korporasi publik/bisnis berbasis syariah seharusnya dapat menjadi prototype sebuah lembaga bisnis yang amanah. Hal ini ditunjukkan dengan tanggung jawab pengelolaan tidak hanya pada organisasi secara horizontal diatasnya namun juga kepada masyarakat sebagai stakeholder-nya. Bahkan pertanggungjawaban tidak hanya terbatas pada kesejahteraan manusia tetapi bagi manusia dan mahluk lainnya.

Kerangka konseptual ISR merupakan konsep pelaporan yang berdasarkan ketentuan syariah. ISR tidak hanya membantu pengambilan keputusan bagi pihak muslim melainkan juga untuk membantu perusahaan dalam melakukan pemenuhan kewajiban terhadap Allah dan masyarakat dan sebagai solusi atas keterbatasam pelaporan sosial konvensional. Secara khusus konsep ISR adalah perluasan dari standar pelaporan kinerja sosial yang meliputi harapan masyarakat tidak hanya mengenai peran perusahaan dalam perekonomian, tetapi juga

${ }^{68}$ Bayu Tri Cahya, “Islamic Social Report... , h. 179 peran perusahaan dalam perspektif spiritual. Selain itu indeks ini juga menekankan pada keadilan sosial terkait mengenai lingkungan, hak minoritas, dan karyawan.Berdasar atas hasil penelitan-penelitian terdahulu dapat diketahui bahwa unsur pengungkapan yang memperhatikan indeks ISR belum mencapai hasil yang benarbenar maksimal, namun sudah cukup akuntabel. Meskipun terdapat aturan mengenai kewajiban sosial pada perusahaan perusahaan di Indonesia, namun belum cukup kuat dalam penegakan dan pengawasan oleh pihak regulator. Oleh karena itu, perlu adanya penegakan hukum yang jelas dan tegas mengenai aturan-aturan pelaporan sosial berbasis Islami oleh entitas berbasis syariah.

\section{Pustaka Acuan}

Abdillah, Muhammad Abi, Sunan ibnu Majjah, Istanbul: Dar Da'wah, 1992.

Arsad, Syahiza, Roshima Said, Haslinda Yusoff, Yusuf Haji-Othman dan Rahayati Ahmad, "The Relationship between Islamic Corporate Social Responsibilityand Firm's Performance: Empirical Evidence from Shari'ah Compliant Companies", European Journal of Business and Management, Vol.6, No.36, 2014.

Cahya, Bayu Tri dan Umi Hanifah, "Meretas Aktualitas Islamic Social Report: Sebagai Corporate Social Responsibilities Framing Berbasis Syariah (Dalam Pendekatan Filosofis)", Jurnal BISNIS, Vol. 4, No. 1, Juni 2016.

Cahya, Bayu Tri, "Islamic Social Report: Ditinjau Dari Aspek Corporate Governance Strength, Media Exposure Dan Karakteristik Perusahaan Berbasis Syariah Di Indonesia Serta Dampaknya Terhadap Nilai Perusahaan", Disertasi, Medan: Program Doktor Ekonomi Syariah Pascasarjana UINSU, 2017.

Cahya, Bayu Tri, A. Nuruddin dan A. Ikhsan, "Islamic Social Reporting: From the Perspectives of Corporate Governance Strength, Media Exposure and the Characteristics of Sharia Based Companies in Indonesia and its Impact On Firm Value" IOSR Journal Of Humanities And Social Science (IOSR-JHSS,) Vol. 22, Issue 5, Ver. 10, May. 2017. 
Dusuki, A. W. and I.A. Nurdianawati, "Maqasid al-Shari'ah, Maslahah and Corporate Social Responsibility". The American Journal of Islamic Social Sciences, Vo. 24, No. 1, 2007.

Farook, S., M. Kabir Hassan, M and R. Lanis, "Determinants of corporate social responsibility disclosure: the case of Islamic banks",Journal of Islamic Accounting and Business Research,Vol. 2, No. 2, 2011.

Farook, Sayd,"Social Responsibility for Islamic Financial Institutions: Laying Down a Framework". Journal of Islamic Economics, Banking and Finance, 2009.

Fitria, Sorayadan Dwi Hartanti. Islam Dan Tanggung Jawab Sosial:"Studi Perbandingan Pengungkapan Berdasarkan Global Reporting Initiative Indeks Dan Islamic Social Reporting Indeks". Purwokerto: Simposium Nasional Akuntansi 13, 2010.

Ghazâli, Abu Hamid Muhammas ibn Muhammad al-, Al-Mustafa, Beirut: Dar Ihya al-Turâth al'Arabi, 1997.

Haniffa, R.,"Social Reporting Disclosure-An Islamic Perspective", Indonesian Management \& Accounting Research, Vol. 2, 2002.

Hassan, A. and S. Syafri Harahap,"Exploring corporate social responsibility disclosure: the case of Islamic banks", International Journal of Islamic and Middle Eastern Finance and Management, Vol. 3, No. 3, 2010.

Islahi, A.A., Economic Concept of Ibn Taymiya, London: Islamic Foundation, 1988.

Ikhsan, Arfan, Sukma Lesmana dan Atma Hayat, Teori Akuntansi", Jakarta: Citapustaka Media, 2015.

Katsîr, Ibnu, Lubâbut tafsir min Ibnu Katsîr, diterjemahkan tafsir Ibnu Katsir oleh $M$. Abdul Ghoffar E.M., Abdurrahim Mu'thi, Abu Ihsan Al-Atsari; pengedit, $M$ Yusuf Harun et al, Bogor: Pustaka Imam Asy-Syafi-I, 2004

Kamal, H. Mohd, Worldview Orientation and Ethics: A Muslim Perspective, In Ethics in Business and Management Islamic and Mainstream Approcahes, London: Asean Academic Press, 2002.

Kamla, R. and H. G. Rammal, "Social reporting by Islamic banks: does social justice matter?" Accounting, Auditing and Accountability Journal", Vol. 26, No. 6, 2013.
Maali, B.,P. Cassonand C Napier,"Social Reporting by Islamic Banks", ABACUS,Vol.42, No. 2, 2006.

Naisaburiy, Imam Abi al-Husain Muslim bin alHajjaj al-Qusyairi an-, Shahih Muslim, Beirut: Dar al-Kitab al-Imaniyah,1995.

Othman, Rohana and A. M. Thani, "Islamic social reporting of listed companies in Malaysia", International Business \& Economics Research Journal, Vol 9, No. 4, 2010.

Othman, Rohana, A. Md. Thani, dan E.K. Ghani, "Determinants of Islamic Social Reporting Among Top Shariah-Approved Companies in Bursa Malaysia", Research Journal of International Studies, Vol. 12, 2009.

Ruslinda, S, "Realising Maqasid Al-Shariah in Islamic Financial Planning", The 4E Journal Islamic Finance, January-March, 2011.

Saridona, Resa dan Cahyandito, Martha Fani, "Social Performance of Indonesia Islamic Banking: Analysis of Islamic Social Reporting Index", International Conference on Economics and Banking, 2015.

Shahata, Shauqi Isumail, Financial Accounting from the Islamic Point of View (nazariya al-muhasaba al-maliya min manzur islami), Cairo:al-zahra al a'lam al-arabi, 1988.

Shawkani, Al-, Irshsad al-fuhul, Beirut: Mu'assasat al-Kutub al-Thaqafiyyah.1995.

Siwar, C. dan M. T. Hossain "An analysis of Islamic CSR concept and th opinion of Malaysian managers", Management of Environmental Quality: An International Journal, 2009.

Sofyani, H. I. Ulum, Daniel Syam dan Sri Wahyuni L, "Islamic Social Reporting Index Sebagai Model Pengukuran Kinerja Sosial Perbankan Syariah (Studi Komparasi Indonesia Dan Malaysia)", Jurnal Dinamika Akuntansi, Vol. 4, No. 1, Maret 2012.

Sofyani, Hafiez "Islamic Social Reporting Perbankan Syariah Di Indonesia, Malaysia Dan Saudi Arabia: Sebuah Studi Menggunakan Anova", Summary Research, Fakultas Ekonomika dan Bisnis. Universitas Gadjah Mada, Yogyakarta, 2014.

Somogyi, J. Do, "The in the Quran and Hadith", Muslim Word, Vol 52, 1962.

Suhendi, Hendi, Fiqh Muamalah, Bandung: Gunung Djati Press, 1997. 
Watt, W. Montgomery "The Influennce of Islam on Medieval Europe (Chichukai Sekai no Isurama)", terj.Wataru Miki, Tokyo: Chikuma Shobo, 1972.
Yusuf, Muhammad Yasir, Islamic Corporate Social Responsibility (I-CSR) pada lembaga keuangan syariah: Teori dan Praktik, Depok: Kencana, 2017. 